\title{
Constitutionally Entrenched Voice to Parliament: Representation and Good Governance
}

\author{
Dani Larkin* and Kate Galloway ${ }^{* *}$ \\ I. Introduction
}

Amidst the throes of the Indigenous Voice co-design process which is currently investigating ways in which Aboriginal and Torres Strait Islander peoples could and should be recognised within the Australian system of government, this article examines the proposal for a constitutionally enshrined Voice to Parliament as envisaged in the Uluru Statement from the Heart. ${ }^{1}$ In particular, we analyse two key features of Voice that have attracted considerable attention. The first of these is the meaning of Voice as 'representative', and the second is the rationale for constitutional enshrinement.

Part II provides the background of the journey of Indigenous constitutional recognition, culminating in the Voice proposal. Part III explains the meaning of the Voice as 'representative', distinguishing principles of representation within a parliamentary democracy in the Westminster tradition, from collective cultural representation. In Part IV, we suggest that to institutionalise cultural representation will enhance good government where the institution adheres to principles of good governance. We conclude that to achieve these principles requires constitutional enshrinement of the Voice to Parliament.

\section{The Journey of Indigenous Constitutional Recognition and the Voice}

We commence this discussion from the understanding that sovereignty in the land mass of Australia has not been ceded. On this basis, we recognize that First Nations peoples in this

country have, since colonization, maintained their identity as sovereign peoples. ${ }^{2}$ The contemporary iteration of the ongoing assertion of status as First Nations has involved, amongst other things, advocacy for constitutional recognition.

In 1999, then Prime Minister John Howard endorsed Indigenous constitutional recognition by way of a proposal for symbolic words of acknowledgement in the Preamble to the Australian Constitution. ${ }^{3}$ The proposal, lacking in any substantive constitutional change, failed to gain 
support from Aboriginal and Torres Strait Islander communities. ${ }^{4}$ It was already apparent from long running assertions by First Nations of their status as such. ${ }^{5}$ And it was certainly clear from that point that Indigenous Australians would not support tokenism, minimalism or symbolism in recognition in law and policy reform as first peoples. ${ }^{6}$

Since 1999, movement towards substantive constitutional recognition has gained traction. In 2012 the Expert Panel on Constitutional Recognition of Indigenous Australians was created. However, rather than adopt the recommendations of the Expert Panel, the government established the Referendum Council in 2015. It was the Referendum Council that led to the First Nations Regional Dialogues and the National Constitutional Convention at Uluru in $2017 .{ }^{7}$ The Regional Dialogues process, a grassroots engagement of Aboriginal and Torres Strait Islander people, ${ }^{8}$ resulted in a consensus that constitutional recognition could only comprise a constitutionally enshrined Indigenous Voice to Parliament. This conclusion was affirmed in the Uluru Statement from the Heart 2017.

A First Nations constitutionally enshrined Voice to Parliament is a contemporary, conservative and sophisticated Commonwealth law and policy reform proposal. It arises from consultation during 2016-17 with Indigenous Australian delegates who participated in 12 regional dialogues culminating in a National Constitutional Convention at Uluru. The process of consultation was instigated by the work and aspirations of the Referendum Council. This was the first time Australia had ever engaged in consultation with Indigenous Australians on this scale and for such issues surrounding their political and cultural empowerment.

The Uluru Statement from the Heart centers itself with three core pillars of law reform proposals which are thematically and purposefully sequenced as Voice, Treaty and Truth. The Voice proposal reflects a justified call for Indigenous political inclusion in law and policy decisionmaking processes.

Dialogue delegates and founders of the Uluru Statement from the Heart intended the Voice proposal to be an Indigenous representative body, constitutionally enshrined, with the key function of directly advising both chambers of Parliament on laws and policies that affect Indigenous people and affairs. Delegates were also open to the Voice taking on an additional advisory function that would make recommendations on the effectiveness of Indigenous servicedelivery agencies. ${ }^{9}$ Importantly, Uluru Statement from the Heart is directed to the Australian 
people. It is not an appeal to government only to be put on display in Parliament alongside previous entreaties.

Since its publication, interpretation of the Voice has been limited by the Minister for Indigenous Australians ${ }^{10}$ and others, ${ }^{11}$ all of whom lacked involvement in the Dialogues process and who ignore its import. To ignore the genesis of the proposals ignores the aspirations of Dialogue delegates and misrepresents the intent of the Voice proposal expressed in the Uluru Statement from the Heart.

The Minister for Indigenous Australians has publicly stated his preference for the Voice to be legislated rather than constitutionally enshrined. ${ }^{12}$ This position is, however, one of high risk in terms of sustainable and meaningful reform. It ignores the longstanding history in Australia of extinguishment of statutory national Indigenous representative bodies. ${ }^{13}$ As was clear from the consensus arising from the Dialogues, constitutional protection of a body like the Voice is essential to advance and protect national political inclusion of Indigenous people within existing governance structures.

Although government policy apparently sees constitutional amendment remain on the table, ${ }^{14}$ Prime Minister Scott Morrison has recently declared that 'it had never been the government's policy to stage a referendum on the Voice. ${ }^{15}$ Against this background, a government process for co-designing an Indigenous Voice remains on foot. ${ }^{16}$ Three appointed advisory groups have put together options as to the form of the Voice, its functionality, its links with regional Voices and those of lower levels of government, and how its membership should be constructed. Notably, the Terms of Reference for this inquiry omitted the question of its constitutional enshrinement. Further, potential submitters have been warned that for their submission to be heard, they should not include commentary on issues that fall outside the terms of reference, including arguments for the Voice's constitutional enshrinement. ${ }^{17}$ It was hardly surprising when the Indigenous Voice Co-Design Interim Report' ('Interim Report') ${ }^{18}$ contained no reference to constitutional amendment.

Constitutional enshrinement is an essential component of the sustainability of a Voice to Parliament. It speaks also to the likelihood of success of the institution. We suggest that this will be driven by the standing of Voice as a representation of First Nations cultures within Australian political processes. 


\section{The Meaning of 'Representation'}

It is trite to observe that Australia is a representative democracy. However, this observation is the starting point for understanding the role of the Voice to Parliament as constitutionally embedded within Australia's institutions of governance.

Then Prime Minister Malcolm Turnbull's characterization of the Voice to Parliament as a 'third chamber ${ }^{19}$ mischaracterizes its representative nature, conflating it with the existing organs of State. We suggest that rather than an institution affording additional representation of 'the people ${ }^{20}$ within law-making processes, a constitutionally enshrined Voice to Parliament allows for cultural representation of First Nations peoples before the law makers themselves. Voice is a cultural collective seeking not to overtake the tenets of parliamentary process in the Westminster tradition, but rather to manifest cultural self-determination within that tradition.

For the Voice, then, representation is collective and it is based on and has its authority in cultural identity grounded in connection to country, traditional language groups, and bloodline. ${ }^{21}$ Those key components of Indigenous cultural identity are also critical for determining membership of Indigenous bodies such as the Voice, providing a collective that represents cultural experience we know to be foreign to the institution of Parliament - absent its individual Aboriginal and Torres Strait Islander members.

By contrast with a cultural construction of representation at the heart of the purpose of Voice, the Interim Report imposes a legalistic Anglo-Australian conception of 'eligibility' to participate in Voice that does not fit the experience of First Nations peoples. ${ }^{22}$ One criterion, for example, requires potential candidates to be an Australian citizen - the constitutional benchmark of eligibility to sit in Parliament itself. Beyond the blindness to the cultural intent of Voice, this is potentially problematic for a number of reasons.

First, whilst the majority of Indigenous Australians are citizens because it has been conferred or deemed under the Australian Citizenship Act 2007 (Cth) and its predecessors, many choose to identify according to cultural identity focused on the names of their language groups or tribes. This is how First Nations derive belonging, place and peoplehood: in relationship with land. ${ }^{23}$ 
Secondly, this criterion fails to acknowledge the contemporary legal appreciation of legal status according to connection to country and clan group of Aboriginal people as a result of the High Court of Australia handing down its decision in 2020 in Love, Thoms $v$ Commonwealth ('Love'). ${ }^{24}$

In Love, the High Court acknowledged the increasing incidence of Aboriginal people born in another country yet having a parent who is an Aboriginal Australian. Consequently, these people are required to hold a visa to enter Australia in accordance with the Migration Act 1958 (Cth). But they are also liable to deportation and exclusion from Australia if they breach visa conditions. As occurred to the complainants in Love, such people might be deemed an 'unlawful non-citizen' ${ }^{25}$ However, the High Court recognized that Aboriginal people belong to Australia and so cannot be deported even if they are not Australian citizens under statute. ${ }^{26}$

Love highlights that even without considering cultural identity that is relevant to Indigenous peoples, a formal citizenship requirement will limit qualifying First Nations candidates by excluding those Aboriginal and Torres Strait Islander people who fall into the non-citizen, nonalien category. This requirement echoes the original misapprehension of the representative nature of the Voice, by seeking to impose the same threshold requirements as those for membership of the Parliament itself.

In a further inappropriate limitation for participation in Voice, the Interim Report limits candidate eligibility for persons with 'certain criminal convictions'. ${ }^{27}$ The Uluru Statement from the Heart acknowledges that proportionally, Indigenous Australians are the most incarcerated people on the planet despite Indigenous Australians not being innately criminal people. This is the torment of the powerlessness of Indigenous Australians that contributes to their disenfranchisement within the institutions of so-called representative government. To refuse membership of a cultural collective for the very reason that it is needed, ignores the nature and purpose of the Voice.

Finally, there remains a broader question of what 'representation' means to Indigenous people of Australia generally, and how Dialogue delegates in particular envisioned the Voice would function in relationship with Parliament. 
Dialogue delegates were clear in their discussions and deliberations on how an Indigenous Voice would function and were adamant about needing an ability to have a say within parliamentary law-making processes on matters affecting cultural affairs. ${ }^{28}$ Delegates wanted the ability to directly access and speak to both chambers of Parliament through nationally selected, or elected, Voice members.

Rubenstein points out that the Uluru Statement from the Heart, in particular through a constitutionally enshrined Voice to Parliament, 'speaks to an inclusive understanding of all aspects of citizenship, in its structural framing in order to provide a meaningful expression of [First Nations'] formal legal status'. ${ }^{29}$ She describes this as 'active citizenship', embracing 'legal status, human rights, political participation, and as identity. ${ }^{30}$ Derived as it is from a consensus approach amongst First Nations peoples to constitutional reform, and given its intent in promoting Indigenous political participation, Voice enhances the relationship between government and those governed through the mechanism of engaged citizenry.

In addition to promoting agency amongst First Nations people, collective cultural representation within political decision-making processes would ensure accountability in the relationship between Indigenous Australians on the one hand, and the Parliament and Executive on the other. Given the non-justiciability of the proposed Voice and its lack of veto power, ministerial accountability is a vital component of the institutional arrangements of Voice. The soft mechanism of accountability is the sole means by which government might be held responsible to consult with the Voice when there is an unequivocal reason to do so.

Importantly, institutionalising direct access to both chambers of Parliament avoids the need to rely on ad hoc appearances before parliamentary committees. The committee system is an indirect means of bringing issues to the attention of law makers. The process will, of course, remain open to individuals and groups who wish to make representations outside the operation of Voice. However, a constitutionally enshrined Voice will provide consistent cultural representation in matters affecting First Nations people. In this respect, an enshrined Voice would enhance the existing institutional system's capacity for good governance.

\section{Enhancing Good Governance}


Along with the sovereignty claimed by the Australian State (and Australian states) is legitimate authority to govern. Implementing the Westminster system of state governance in a federation, the institutions of state adhere to principles including responsible government and parliamentary government. Underpinning the system are principles of good government: 'fairness in administration, the predictability of official actions, the morality of decisions affecting individuals and equality before the law. ${ }^{31}$

More broadly than good government, good governance provides for distribution of authority and power amongst a variety of stakeholders, together with the means of exercising them. To achieve such distribution involves institutional capacity for 'sound decision-making, representation and accountability'. ${ }^{32}$ Dodson and Smith identify four key attributes of good governance: legitimacy, power, resources, and accountability. ${ }^{33}$ Importantly also in the context of Indigenous communities, they observe the importance of 'stable and broadly representative organisational structures' ${ }^{34}$ in promoting effective governance. Given the role of Voice to enhance lawmaking capability in contexts affecting First Nations peoples, we suggest that these components of the principle of good governance overlap with those traditionally associated with good government. We address each of them in turn.

First, without an institutional appreciation for culture, Parliament lacks both the ability and the legitimacy to engage appropriately with First Nations peoples. Consequently, Indigenous people's power to engage collectively with the Australian polity - a feature of self-determination and active citizenship ${ }^{35}$ - is ignored or disrespected. ${ }^{36}$ As a result, resources that might effect good governance in Indigenous contexts are malapportioned with all the consequences that entails. ${ }^{37}$ Ultimately, through First Nations' ensuing disengagement with the broader polity, government is not held to account for adverse outcomes.

Secondly, there are increasing calls for governmental accountability in terms of free, prior, and informed consent on matters affecting First Nations peoples.

The first of these issues reflects a failure of existing institutions of governance, and the second highlights the need for an institutional response to connect law makers directly with collective cultural authority as a conduit to comprehending the means of securing that consent. In broad terms, Parliament and the Executive cannot fulfil the promise of good government in matters concerning Indigenous people without tackling questions of good governance. The challenge for 
the Australian government is how it engages with culturally appropriate governance structures of First Nations, within Australian law and governance structures. The answer to this challenge lies in the proposals within the Uluru Statement.

Uluru Statement from the Heart provides the blueprint for Makarrata, the bringing together of the Australian polity and First Nations after a struggle. The three key reform proposals, Voice, Treaty and Truth-Telling, ${ }^{38}$ make clear that the path towards conciliation between Australian institutions and First Nations is for the old structures to change, allowing for new structures that politically and constitutionally incorporate First Nation perspectives in the very fabric of the nation's law making.

The Voice to Parliament is thus an institutional response to questions of good governance. Through its very presence - an institution established under the Constitution and comprised of Aboriginal and Torres Strait Islander people - - legitimizes the place of First Nations peoples within Australian government. Its collective cultural representation can afford legitimacy to laws and policy affecting First Nations people, empowering a collective voice hitherto not uplifted within colonial institutions of government. The legitimacy that is central to good governance, and the exercise of collective self-determination that comes with that, are afforded in particular through the referendum process necessary for constitutional enshrinement of Voice to Parliament. Legitimacy is important not only within First Nations communities, but also throughout the wider Australian polity.

Additionally, to provide effective governance, Voice requires resources. Constitutional enshrinement will require that the Voice be given sufficient resources, still within the discretion of the Parliament, to fulfill its constitutional function.

Finally, constitutional enshrinement will allow the means of holding government to account through the institution of the Voice, and thus to First Nations people.

Current proposals are focused on a statutory body: a voice to government, without constitutional enshrinement. Such a model will not live up to the principles of cultural representation or to good governance that are the hallmarks of Voice to Parliament proposed by the Uluru Statement from the Heart. 
First, a Voice that is legislated without constitutional enshrinement would lack the legitimacy engendered through referendum preceding constitutional amendment. It would simply be an institution of the Parliament and subject to the vagaries of government policy, rather than an institution created as the will of the broader polity. A statutory body, when handing down its deliberations, would have less authority than one that has the backing of the people.

Secondly, experience shows that a statutory organisation can easily be starved of resources until it is shut down altogether. This is not the case for a constitutionally enshrined institution that would require a budget to be able to fulfill its functions.

Finally, to promote the ideal of active citizenship requires equalizing the relationship between government and the governed - notably through consent of the governed. A statutory body is effectively imposed upon the community through the will of Parliament, thus lacking the agency of those who are governed. The Regional Dialogues, and then a referendum, together represent a form of agency by First Nations as well as the polity broadly, that are the hallmarks of active citizenship.

For these reasons, a statutory Voice to government will fall short of the hopes and expectations for institutionalized First Nations engagement in our systems of governance.

\section{Conclusion}

As explained at Uluru, sovereignty is not a legal concept but 'a spiritual notion', predicated on Indigenous Australians' ancestral ties to land and community. Assertions of Indigenous sovereignty therefore do not necessarily call for legal secession. Instead, they represent the aspiration for meaningful institutional change to embed a constitutional relationship built on equal partnership and equal political status.

Constitutional change is desirable to facilitate twin goals. First, of culturally appropriate engagement of First Nations peoples in developing law and policy that affects their lives. And secondly, it seeks to promote good governance within the process of Australian government. As two centuries of poor outcomes of law and government policy have shown, existing institutional structures are inadequate to formulate and enact the changes required. The key to these changes lies in institutional reform that provides cultural representation of First Nations peoples. 
Finally, to promote good government, institutional change must foster the conditions for good governance. To be legitimate, for effective distribution of authority and power, to assure resources, and hold Parliament to account for its decisions requires constitutional authority: a constitutionally enshrined Voice to Parliament.

\footnotetext{
${ }^{*}$ Bundjalung. Lecturer/Deputy Director of the Indigenous Law Centre, UNSW.

${ }^{* *}$ Associate Professor, Griffith Law School.

${ }^{1}$ Uluru Statement from the Heart, 2017.

${ }^{2}$ See, eg, Irene Watson, 'The Future Is Our Past: We Once Were Sovereign and We Still Are' (2012) 8(3)

Indigenous Law Bulletin 12. See also: Mabo v Queensland (No 2) (1992) 175 CLR 1; Henry Reynolds, Aboriginal Sovereignty: Reflections on Race, State and Nation (Allen \& Unwin, NSW, 1996); Sarah Maddison, The Colonial Fantasy Why White Australia Can't Resolve Black Problems (Allen \& Unwin, 2019) 32.

${ }^{3}$ Transcript of the Prime Minister, The Hon. John Howard MP, Press Conference, Prime Minister's Courtyard, Parliament House, 23 March 1999.

${ }^{4}$ George Williams, 'The Forgotten Question' The Australian, 1 November 1999.

${ }^{5}$ Including through: Yirkkala Bark Petition (1963) <https://www.foundingdocs.gov.au/item-did-104.html>; Barunga Statement (1988) <https://aiatsis.gov.au/collections/collections-online/digitised-collections/treaty/barungastatement; Eva Valley Statement (1993) <http://www.atns.net.au/agreement.asp?EntityID=1742>; Kalkiringi Statement $(1998)<$ http://www.austlii.edu.au/au/journals/IndigLawB/1998/73.html>

${ }^{6}$ Michael Mansell, Letter to the Editor, The Sydney Morning Herald (12 February 1999) 16; Peter Yu, Letter to the Editor, The Australian (19 February 1999) 12; Lowitja O'Donoghue in Tony Stephens, 'Preamble Pathetic: O’Donoghue', Sydney Morning Herald (16 April 1999) 7.

${ }^{7}$ Final Report of the Referendum Council (Commonwealth of Australia, 2017) 36; Megan Davis, Voice, Treaty, Truth, The Monthly (July 2018) <https://www.themonthly.com.au/issue/2018/july/1530367200/megan-davis/voicetreaty-truth\#mtr>.

${ }^{8}$ Final Report of the Referendum Council, Ibid.

${ }^{9}$ Ibid 66.

${ }^{10}$ Matthew, Doran, 'Minister Ken Wyatt wants Indigenous voice to government to pass Parliament before next election', ABC News (15 November 2020) <https://www.abc.net.au/news/2020-11-15/ken-wyatt-wants-indigenousvoice-laws-to-pass-before-election/12885306>.

${ }^{11}$ National Indigenous Australians Agency, Indigenous Voice Discussion Paper

${ }^{12}$ Eddie Synot, 'Ken Wyatt's Proposed "Voice to Government" Marks Another Failure to Hear Indigenous Voices' The Conversation (30 October 2019).

${ }^{13}$ Larissa Behrendt, 'The Abolition of ATSIC - Implications for Democracy', Democratic Audit of Australia (2005)

2; Thalia Anthony, 'A New National Indigenous Representative Body... Again' (2010) 7(18) Indigenous Law Bulletin, 5.

14 'Federal Budget Money for Indigenous Voice' SBS News (4 April 2019) <https://www.sbs.com.au/news/federalbudget-money-for-indigenous-voice>; Megan Davis, 'Constitutional Recognition: Two Decades On', Australian Public Law (Australian Public Law Blog, 1 March 2021) <https://auspublaw.org/2021/03/constitutional-recognitiontwo-decadeson/\#: :text=The\%20government\%20appears\%20committed\%20to,Voice $\% 20$ model $\% 20$ has\%20been\%20determine $\mathrm{d}>$.

${ }^{15}$ Rob Harris, "Not our Policy": Scott Morrison Rejects Push for Referendum on Voice' Sydney Morning Herald (18 March 2021) <https://www.smh.com.au/politics/federal/not-our-policy-scott-morrison-rejects-push-forreferendum-on-voice-20210318-p57bxc.html>.

${ }^{16}$ National Indigenous Australians Agency, Membership of Local and Regional Indigenous Voice Co-Design Group (4 March 2020) <https://ministers.pmc.gov.au/wyatt/2020/membership-local-and-regional-indigenous-voice-codesign-group $>$.

${ }^{17}$ Ibid 175.

${ }^{18}$ National Indigenous Australians Agency, Interim Report to the Australian Government (October 2020) $<$ https://static1.squarespace.com/static/593785818419c208a99c3350/t/600e451ccf90a952736216fa/1611547958019/ indigenous-voice-codesign-process-interim-report-2020.pdf $>$.
} 
${ }^{19}$ Malcolm Turnbull 29th Prime Minister of Australia 2015-2018, 'Response to Referendum Council's report on Constitutional Recognition' (Media Release, 26 October 2017); Elliot Johnston, 'Malcolm Turnbull's Big LetDown' (2018) 87 Australian Options 4, 4-6. See also, Dani Larkin and Kate Galloway, 'Uluru Statement from the Heart: Australian Public Law Pluralism' (2018) 30(2) Bond Law Review 1.

${ }^{20}$ Constitution of the Commonwealth of Australia, ch 1; Roach v Electoral Commissioner (2007) 233 CLR 162, [112] (Gummow, Kirby, Crennan JJ).

${ }^{21}$ Francesca Merlan, 'Land, Language and Social Identity in Aboriginal Australia' 13 (2) Mankind 133, 134-5.

${ }^{22}$ National Indigenous Australians Agency, Interim Report to the Australian Government (October 2020) 41

$<\mathrm{https} / / /$ static1.squarespace.com/static/593785818419c208a99c3350/t/600e451ccf90a952736216fa/1611547958019/ indigenous-voice-codesign-process-interim-report-2020.pdf>.

${ }^{23}$ Aileen Moreton-Robinson, Sovereign Subjects: Indigenous Sovereignty Matters (Allen \& Unwin, 2007); Sally Morgan, 'The Balance for the World' in S Morgan, T Mia and B Kwaymullina (eds), Heartsick for Country: Stories of Love, Spirit and Creation (Freemantle Press, 2008) 253; Bronwyn Fredericks, “"We Don't Leave Our Identities at the City Limits": Aboriginal and Torres Strait Islander People Living in Urban Localities' 1 The Journal of the Australian Institute of Aboriginal and Torres Strait Islander Studies 4.

${ }^{24}$ Love v Commonwealth; Thoms v Commonwealth [2020] HCA 3.

${ }^{25}$ Migration Act 1958 (Cth), s189.

${ }^{26}$ Love v Commonwealth; Thoms v Commonwealth [2020] HCA 3 [398] per Edelman J.

${ }^{27}$ National Indigenous Australians Agency, Interim Report to the Australian Government (October 2020) 41 $<$ https://static1.squarespace.com/static/593785818419c208a99c3350/t/600e451ccf90a952736216fa/1611547958019/ indigenous-voice-codesign-process-interim-report-2020.pdf $>$.

${ }^{28}$ Final Report of the Referendum Council (Commonwealth of Australia, 2017) 148.

${ }^{29}$ Kim Rubenstein, 'Power, Control and Citizenship: The Uluru Statement from the Heart as Active Citizenship' (2018) 30(1) Bond Law Review 19, 27.

${ }^{30}$ Ibid.

${ }^{31}$ Suri Ratnapala, 'Westminster Democracy and the Separation of Powers: Can they Co-exist?' (1995) Papers on Parliament No 26 (Parliament of Australia).

${ }^{32}$ M Dodson and D E Smith, 'Governance for Sustainable Development: Strategic Issues and Principles for Indigenous Australian Communities' Discussion Paper 250/2003 (Centre for Aboriginal Economic Policy Research) 2.

${ }^{33}$ Ibid 2.

${ }^{34}$ Ibid 13.

${ }^{35}$ Rubenstein (n 29).

${ }^{36}$ Leon Terrill and Sasha Boutilier, 'Indigenous Land Tenure Reform, Self-determination, and Economic Development: Comparing Canada and Australia' (2019) 45(1) University of Western Australia Law Review 35; Maddison (n 2) xxii.

${ }^{37}$ See for example, Michelle Patterson, Commonwealth Machinery of Government in Aboriginal and Torres Strait Islander Affairs: 50 Years of Commonwealth Public Administration in Aboriginal and Torres Strait Islander Affairs (IAG Working Paper Series, No. 1, Aboriginal and Torres Strait Islander Affairs Group, Department of the Prime Minister and Cabinet, May 2017) 14.

${ }^{38}$ Uluru Statement from the Heart, 2017. 